\title{
Effect of Zinc Supplementation on Body Mass Index in Type 2 Diabetics, Interventional Study, Ismailia-Egypt
}

\author{
Almass F. Hassan', Maged S. Khattab', Abdelrauof M. El Deib², Hind M.Salama1, Mohamed A. \\ Mohamed ${ }^{*}$ \\ ${ }^{1}$ Family Medicine Department, Faculty of Medicine, Suez Canal University, Egypt \\ ${ }^{2}$ Internal Medicine Department, Faculty of Medicine, Suez Canal University, Egypt
}

\begin{abstract}
:
Background: Egypt is the 8th in order among the top 10 countries for the number of adults with diabetes; estimated prevalence is $17.3 \%$ in 2017 .Obesity is a chronic disease characterized by excessive accumulation of body fat and associated with the development of comorbidities such as diabetes mellitus, hypertension and dyslipidemia. It is associated with changes in zinc metabolism, which are characterized by reduced plasma concentrations. Zinc may regulate serum leptin concentration and appetite control. Objective: This study was conducted to assess the effect of zinc supplementation on BMI (body mass index) in type 2 diabetics.

Methods: It was a single blinded, randomized, placebo-controlled trial. Patients $(n=200)$ were randomly allocated into two groups: zinc group, \& placebo group, zinc supplementation was given for 12 weeks. Body mass index (BMI) was assessed at baseline \& after 12 weeks. Results: There was no statistically significant difference in BMI in zinc group compared to placebo group after 12 weeks.

Conclusion: Zinc supplementation has no beneficial effect on body mass index in type 2 diabetic patients.

Keywords: type 2 diabetes, zinc supplementation
\end{abstract}

\section{Introduction:}

Diabetes mellitus is one of the world's most prevalent diseases. Type 2 diabetics represent $90 \%$ of all cases of diabetes. Recent reports illustrate advanced increases in its global prevalence. ${ }^{(1)}$ About 425 million adults were living with diabetes in 2017; by 2045 this will rise to 629 million. ${ }^{(2)}$ It was postulated that about $79 \%$ of adults with diabetes were living in middle- and low-income countries. ${ }^{(3)}$ In the Middle East and North Africa Region, 1 in 10 adults suffer from type 2 diabetes. Egypt is the 8th in order among the top 10 countries for number of adults with diabetes; estimated prevalence is $17.3 \%$ in $2017 .{ }^{(4)}$
Obesity is a chronic disease characterized by excessive accumulation of body fat and associated with the development of comorbidities such as diabetes mellitus, arterial hypertension, cardiovascular diseases, and dyslipidemia. ${ }^{(5)}$ Egypt Demographic Survey (2008) found that approximately 50\% of Egyptian men and 65\%-80\% of Egyptian women are overweight or obese. A 2010 World Health Organization (WHO) report indicated that $30.3 \%$ of Egyptian adults are obese. Egypt currently has the third highest prevalence of obesity in the MENA region, after Saudi Arabia and United Arab Emirates.

*Corresponding author: E-mail: marafaku@yahoo.com 
Central adiposity is particularly common among Egyptians and is probably inherited. ${ }^{(6)}$ An important point is that obesity is accompanied by changes in zinc metabolism, which are characterized by reduced plasma concentrations of this mineral compared with eutrophic conditions. ${ }^{(7)}$ Zinc may regulate serum leptin concentration and appetite control. Zinc (Zn), an essential micronutrient and a component of many enzymes, is involved in the synthesis, storage and release of insulin. Studies have reported that $\mathrm{Zn}$ has been implicated in altered lipid markers, insulin resistance, oxidative stress, inflammatory markers, adiposity and serum leptin level. ${ }^{(8)}$

Although there is accumulating evidence on the relationship between serum zinc and human metabolism, there is a lack of evidence on $\mathrm{Zn}$ as a potential therapeutic agent to reduce weight and improve metabolic parameters in obese adults. Thus, this study aimed at evaluating the effects of $\mathrm{Zn}$ supplementation versus placebo on weight reduction in type 2 diabetics.

\section{Subjects and Methods}

Study Design and Setting: This is a single blinded randomized placebo-controlled trial that was conducted among type 2 diabetic patients attending family medicine clinic,
Suez Canal University hospital in Ismailia, Egypt between December 2017 and June 2019.

Study population: All diabetic patients attended the family medicine outpatient clinic during study period, which fulfilled the inclusion criteria and agreed to participate in the study were included.

Inclusion Criteria: Patients with type 2 DM, aged $\geq 18$ years, attending the clinic for a routine follow-up visit, on regular use of oral anti-diabetic drugs (no insulin), with HbAlc concentrations of $7.5-9.5 \%$, not enrolled in similar program in the last 6 months and without taking vitamins or mineral supplements in the previous 2 months.

Exclusion Criteria: Severe or uncontrolled cardiovascular disease (defined as a cardiovascular event within the last year), psychiatric disease or cognitive impairment interfering with treatment compliance and pregnancy or lactating women.

Sample size was calculated with power of $80 \%$ and level of significance at 0.05 based on a previously published study ${ }^{(9)}$ with total enrollment of 200 patients.

Sampling method and Randomization:

During one month period HbAlc was requested to all patients with type 2 diabetes 
mellitus who attended family medicine outpatient clinic of Suez Canal University hospital and fulfill inclusion and exclusion criteria. Patients who had HbA1c 7.5-9.5 were listed in a numerical order and were be arranged alphabetically.

At first the total study participants $(n=200)$ were selected randomly from the numerical list by simple random sampling technique. Then random allocation into groups was done. The study included two groups control $(\mathrm{n}=100)$ and intervention $(\mathrm{n}=100)$. The study participants were randomly allocated into two study groups by simple random sampling technique.

1. The intervention group: (zinc group). The patients in this group (n: 100) were supplemented with oral zinc sulfate $(25 \mathrm{mg})$ in addition to the oral anti-diabetic drugs.

2. The control group: (placebo group). The patients in this group (n: 100) were supplemented with oral placebo in addition to the oral anti-diabetic drugs.

\section{Methods}

Information on age, sex, location, educational level, occupation diabetic duration, drug usage, diabetic complications and adherence to healthy diet were obtained by an interview questionnaire that was tested for validity by pilot study on 20 patients(not included in the study sample) before starting the current study.

Patients of both groups were instructed to take either $25 \mathrm{mg}$ of zinc sulfate or placebo once daily for a period of 12 weeks, both drugs were identical in formulation, shape, size, weight, texture, and packing. Patients were allowed to ask questions regarding any possible side effects and the degree of compliance was followed at the $4^{\text {th }}, 8^{\text {th }}$ and $12^{\text {th }}$ week from beginning of the study by patient interview and pill counts; those taking $\geq 90 \%$ (e.g. $\geq 25$ capsules zinc $\backslash 4$ weeks) of the drugs were considered compliant. Adherence to oral anti-diabetic drugs and healthy diet was assessed by interviewers at every visit. Two patients from intervention group were withdrawn after 8 weeks of the study as her anti diabetic therapy was changed to insulin. Three patients from control group were withdrawn after 4 weeks of the study without mentioning causes.

Body mass index(BMI) was calculated as weight in kilograms divided by the square of height in meters $\left(\mathrm{kg} / \mathrm{m}^{2}\right)^{(10)}$ for all patients (in both zinc and placebo groups) before starting treatment (baseline values) and then after 12 weeks of treatment to monitor the change in body mass index.

\section{Statistical analysis}


Statistical analysis was performed using Statistical Package for the Social Sciences (SPSS 18.0) statistical program. Numerical values were expressed as mean +standard deviation (SD). Continuous variables were compared using the independent-samples $t$ test. Chi-Square test was used to compare categorical variables between groups. P value of $<0.05$ was considered statistically significant.

\section{Compliance with ethical standards}

Ethical approval: All procedures performed in the study were approved and in accordance with the ethical standards of the institutional research committee of Faculty of Medicine Suez Canal University and with the 1964 Helsinki declaration and its later amendments.

Informed consent: Informed consent was obtained from all individual participants before commencing the study.

\section{Results:}

Out of 200 patients selected at the beginning of the research, 195 patients completed this study. Two patients in zinc group and three patients in the placebo group had withdrawn. Most of the patients in the study groups were not adherent to dietary recommendations (69\%, 73\% in intervention and control group respectively) Comparison of the baseline characteristics of both groups revealed no significant differences (Table 1).

Regarding adherence to Zinc or placebo after 12 weeks, most patients in the two groups achieved good adherence to zinc supplementation(93.9\%) or placebo(94.8\%),and the difference was not statistically significant ( $\mathrm{p}$-value $=0.756$ ).

Body mass index comparison at baseline showed statistically significant difference between the intervention group $(31.6 \pm 3.19)$ and placebo group $(30.42 \pm 3.03)(\mathrm{p}=0.007)$. Although both groups achieved some reduction in BMI after 12 weeks of zinc or placebo supplementation $(30.98 \pm 3.41$ and $30.15 \pm 3.061$ in intervention and placebo group respectively), the change in BMI in zinc group compared to that in placebo group wasn`t statistically significant $(\mathrm{p}=0.0 .032)$ (Table 2)

\section{Discussion:}

The results of the current study were matching with the results of a study conducted in Iran which found no statistically significant differences in BMI prior to and after zinc treatment. ${ }^{(11)}$ Another study in Iran reported that there wasn't significant decrease in weight as BMI decreased from $28.33 \pm 6.6$ to $26.75 \pm 5.08 \mathrm{~kg} / \mathrm{m}^{2}$ in the zinc group and 
decreased from $26.86 \pm 5.15$ to $26.75 \pm 5.08$ $\mathrm{kg} / \mathrm{m}^{2}(\mathrm{P}=0.16)$ in control group. ${ }^{(12)}$

Similarly in Sirilanka a study evaluating zinc supplementation in prediabetes found that there wasn't significant decrease in BMI (body mass index) after zinc supplementation for 1 year in pre-diabetic patients. ${ }^{(13)}$

In contrast to our results in Chile the researchers found that 1-year of intervention with $30 \mathrm{mg}$ /day zinc supplementation had significant effect on BMI $(\mathrm{P}=0.003)$. These contradicted results may be related to different study population, longer duration of zinc supplementation or different dose. ${ }^{(14)}$

Conclusion: It can be concluded that Zinc supplementation has no beneficial effect on body mass index in type 2 diabetic patients however further studies using different doses and durations, in more than one center may be needed.

Study limitation: The results of the current study may be limited by that it was single center study, which may reduce its generalizability.

Conflict of interest: The authors declare that they have no conflict of interest.

\section{References:}

1. Abbas MT, Hadi N. Review Diabetes Mellitus: A review. Karbala journal of pharmaceutical science. 2018(15):80-91.
2. Forouhi NG, Wareham NJ. Epidemiology of diabetes. Medicine. 2019; 47(1):22-27.

3. Zheng Y, Ley SH, Hu FB. Global aetiology and epidemiology of type2 diabetes mellitus and its complications. Nature Reviews Endocrinology. 2018;14(2):88.

4. Cho N, Shaw J, Karuranga S, Huang Y, da Rocha Fernandes J, Ohlrogge A, et al. IDF Diabetes Atlas: Global estimates of diabetes prevalence for 2017 and projections for 2045. Diabetes research and clinical practice. 2018;138:271-81.

5. Piché M-E, Poirier P, Lemieux I, Després J-P. Overview of epidemiology and contribution of obesity and body fat distribution to cardiovascular disease: an update. Progress in cardiovascular diseases. 2018;61(2):103-13.

6. Hegazi R, El-Gamal M, Abdel-Hady N, Hamdy O. Epidemiology of and risk factors for type 2 diabetes in Egypt. Annals of global health. 2015;81(6):81420.

7. Severo JS, Morais JBS, Beserra JB, dos Santos LR, de Sousa MeloSR, de Sousa $\mathrm{GS}$, et al. Role of Zinc in Zinc- $\alpha 2$ Glycoprotein Metabolism in Obesity: a 
Review of Literature. Biological trace element research. 2019:1-8.

8. El-Mashad GM, El-Gebally E-SI, ElHefnawy SM, Saad AME-S. Effect of zinc supplementation on serumzinc and leptin levels in children on regular hemodialysis. Menoufia Medical Journal. 2018;31(2):664.

9. El-Ashmony SMA, Morsi HK, Abdelhafez AM. Effect of zinc supplementation on glycemic control, lipid profile, and renal functions in patients with typeII diabetes: a single blinded, randomized, placebo-controlled, trial. J Biol Agric Health. 2012;2:33-7.

10. Eckel N, Li Y, Kuxhaus O, Stefan N, Hu FB, Schulze MB. Transition from metabolic healthy to unhealthy phenotypes and association with cardiovascular disease risk across BMI categories in 90257 women (the Nurses' Health Study): 30 year follow-up from a prospective cohort study. The lancet Diabetes \& endocrinology. 2018;6(9):714-24.

11. Parham M, Amini M, Aminorroaya A, Heidarian E. Effect of zinc supplementation on microalbuminuria in patients with type 2 diabetes: a double blind, randomized, placebo-controlled, cross-over trial. The review of diabetic studies: RDS. 2008;5(2):102.

12. Afkhami-Ardekani M, Karimi M, Mohammadi SM, Nourani F. Effect ofzinc sulfate supplementation on lipid and glucose in type 2 diabetic patients. Pak J Nutr. 2008;7(4):550-3.

13. Ranasinghe P, Wathurapatha WS, Galappatthy P, Katulanda P, Jayawardena R, Constantine GR. Zinc supplementation in prediabetes: A randomized double-blind placebo-controlled clinical trial: Journal of diabetes. 2018;10(5):386-97.

14. Pérez A, Rojas P, Carrasco F, Basfi-fer K, Pérez-Bravo F, Codoceo J, et al. Zinc supplementation does not affect glucagon response to intravenous glucose and insulin infusion in patients with well-controlled type 2 diabetes. Biological trace element research. 2018;185(2):255-61. 
Table (1): Baseline Characteristics of Patients in intervention and control Groups (n= 200).

\begin{tabular}{|c|c|c|c|c|}
\hline \multirow{2}{*}{ Variables } & \multicolumn{2}{|c|}{ Groups } & \multirow{2}{*}{$\begin{array}{c}\text { test } \\
\text { value }\end{array}$} & \multirow[t]{2}{*}{ p-value } \\
\hline & $\begin{array}{l}\text { Intervention } \\
\qquad(\mathrm{n}=\mathbf{1 0 0})\end{array}$ & $\begin{array}{l}\text { Control } \\
(n=100)\end{array}$ & & \\
\hline Age (years), mean $\pm \mathrm{SD}$ & $48.23 \pm 7.57$ & $49.95 \pm 6.85$ & 1.683 & $0.09^{\mathrm{a}}$ \\
\hline \multicolumn{5}{|l|}{ Gender, n (\%) } \\
\hline Male & $38(38 \%)$ & $45(45 \%)$ & \multirow[t]{2}{*}{1.009} & \multirow[t]{2}{*}{$0.34^{b}$} \\
\hline Female & $62(62 \%)$ & $55(55 \%)$ & & \\
\hline \multicolumn{5}{|l|}{ Residency, n (\%) } \\
\hline Urban & $80(80 \%)$ & $82(82 \%)$ & 1.085 & $0.296^{\mathrm{b}}$ \\
\hline Rural & $20(20 \%)$ & $18(18 \%)$ & & \\
\hline \multicolumn{5}{|l|}{ Occupation } \\
\hline Nonworking & $55(55 \%)$ & $62(62 \%)$ & \multirow[t]{3}{*}{1.837} & \multirow[t]{3}{*}{$0.399^{b}$} \\
\hline Unskilled manual worker & $27(27 \%)$ & $19(19 \%)$ & & \\
\hline $\begin{array}{l}\text { Skilled manual worker or } \\
\text { Trades or Semi- } \\
\text { professional }\end{array}$ & $18(18 \%)$ & $19(19 \%)$ & & \\
\hline $\begin{array}{l}\text { Adherence to dietary } \\
\text { recommendations }\end{array}$ & & & & \\
\hline Adherent & $28(28 \%)$ & $27(27 \%)$ & 0.025 & $0.874^{\mathrm{b}}$ \\
\hline Non-adherent & $72(72 \%)$ & $73(73 \%)$ & & \\
\hline
\end{tabular}

\section{* Statistically significant}

${ }^{\mathrm{a}}$ values are based on Independent-samples $t$ test. Statistical significance at $\mathrm{P}<0.05$

${ }^{\mathrm{b}}$ values are based on chi-square test. Statistical significance at $\mathrm{P}<0.05$ 
Table (2): Comparison of BMI at base line and after Zinc supplementation or Placebo for 12 weeks in type 2 diabetic patients.

\begin{tabular}{|c|c|c|c|c|}
\hline \multirow{2}{*}{ Variable } & \multicolumn{2}{|c|}{ Groups } & \multirow{2}{*}{$\begin{array}{c}\text { test } \\
\text { value }\end{array}$} & p-value \\
\cline { 2 - 4 } & Intervention & Control & 2.702 & $0.007 *$ a \\
\hline $\begin{array}{c}\text { BMI (mean } \pm \text { SD) } \\
\text { at base line }\end{array}$ & $\begin{array}{c}31.60 \pm 3.19 \\
(\mathrm{n}=100)\end{array}$ & $\begin{array}{c}30.42 \pm 3.03 \\
(\mathrm{n}=100)\end{array}$ & 1.806 & 0.032 \\
$\begin{array}{c}\text { BMI (mean } \pm \text { SD) } \\
\text { after 12 weeks }\end{array}$ & $\begin{array}{c}30.98 \pm 3.412 \\
(\mathrm{n}=98)\end{array}$ & $\begin{array}{c}30.15 \pm 3.061 \\
(\mathrm{n}=97)\end{array}$ & \\
\hline
\end{tabular}

${ }^{\mathrm{a}}$ values are based on Independent-samples $t$ test. Statistical significance at $\mathrm{P}<0.05$ 


\section{العربى الملخص}

تأثير مكملات الزنك على مؤشر كتلة الجسم في مرضى السكري من النوع 2 ، دراسة تلخلية ، الإسماعيلية_مصر

$$
\text { الماس فتحى ،ماجد خطاب ،عبد الرؤوف الديب ،هند ميخائيل ،محمد عبد الواحد محمد }
$$

الخلفية: مصر هي الثامنة من بين أكثر10 دول بالنسبة لعدد البالغين المصابين بالسكري ؛ معدل الانتشار المقدر هو 17.3 ٪ في عام 2017. و السمنة مرض مزمن يتسم بالتر اكم المفرط للاهون في الجسم والمرتبط بتطور الأمر اض المصاحبة مثل داء السكري و ارتفاع ضغط الدم وزيادة دهون الدم. ويرتبط ذلك بالتغيرات في استقلاب الزنك ، و التي تتميز بتركيزات بلازما منخفضة. قد ينظم الزنك تركيز اللبتين في الدم و السيطرة على الثهية. الهـف: أجريت هذه الدراسة لتقييم تأثنير مكملات الزنك على مؤشر كتلة الجسم (BMI) في مرضى السكري من النوع 2.الطريقة: كانت تجربة عشوائية أحادية العمى مسيطر عليها، نم تخصيص المرضى (ن = 200) بشكل عشو ائي إلى مجموعتين: مجموعة الزنلك ، ومجموعة الدواء الوهمي ، أعطيت مكملات الزنلك لمدة 12 أسبو عًا. تم تقييم مؤشر كتلة الجسم (نMI) في الأساس وبعد 12 أسبو عا. النتائج: لم يكن هناك فروق ذات دلالة إحصائية في مؤشر كتلة الجسم في مجموعة الزنلك مقارنة بالمجمو عة الثانية بعد 12 أسبوعًا. الخلاصة: مكملات الزنك ليس له تأثير مفيد على مؤشر كتلة الجسم في مرضى السكري من النوع 2. 